\title{
https://doi.org/10.46813/2021-136-038 \\ SECONDARY ELECTRON EMISSION FROM THIN ALUMINIUM FOILS PRODUCED BY HIGH ENERGY ELECTRON BEAMS
}

\author{
S.H. Karpus, G.D. Kovalenko, Yu.H. Kazarinov, V.M. Dubina, \\ V.Y. Kasilov, S.S. Kochetov, O.O. Shopen, I.N. Shliakhov \\ National Science Center "Kharkov Institute of Physics and Technology”, Kharkiv, Ukraine \\ E-mail: kovalenko@kipt.kharkov.ua
}

The description of the experimental equipment and technique for measuring the secondary emission of electrons (SEE) with application of accelerated electrons at the linear accelerator of the IHEPNP NSC KIPT with energies up to $30 \mathrm{MeV}$ and a standard secondary emission monitor [1] are presented. Experimental data of secondary electron emission yields from thin aluminum targets $(8$ and $50 \mu \mathrm{m})$ for primary electron beam energies of 16 and $25 \mathrm{MeV}$ have been experimentally measured. The analysis of the experimental data and their comparison with the theory are carried out. It is shown that the proposed technique for measuring the yields of secondary electron emission is useful and applied for study of low-energy and $\delta$-electrons yields from thin foils, as well as to research the effect of the density effect depending on the energy of the primary electron beam.

PACS: 79.00.00, 06.20.Jr, 07.07.Df

\section{INTRODUCTION}

In the interaction of relativistic electrons with matter, along with other processes, processes of inelastic collision with atoms of matter and scattering by atomic electrons are present. As a result of collisions, the primary particle changes energy and momentum. At the same time, some of the electrons of the substance acquire enough energy to leave it. The phenomenon of electron emission from matter is widely used to register particle beam current [2 - 5]. The spectrum of secondary electrons consists of high-energy electrons with energies greater than $1 \mathrm{keV}$ ( $\delta$-electrons) and low-energy electrons with energies less than $100 \mathrm{eV}$ [5]. High-energy electrons are formed as a result of elastic scattering of the initial electrons by the electrons of the substance, and low-energy electrons - as a result of inelastic interaction with the atoms of the substance. Low-energy electrons, colliding with the electrons of the substance, quickly lose energy and therefore their exit is possible only from a thin layer of the substance of the order of $100 \mathrm{~A}[6]$, in contrast to $\delta$-electrons, which leave the entire volume of the substance.

Monitors consisting of one or several thin foils are applied for registration the current of charged particles [7]. In this experiment, we used a thin aluminum foil with a thickness of 8 and $50 \mu \mathrm{m}$.

The peculiarity of the interaction of relativistic electrons with thin foils is that the interactions with the first and second surfaces are different. This difference is due to the fact that the energy loss of relativistic electrons in a thin layer of matter near the first surface will be greater than in a thin layer near the second surface. It is due to the influence of the density effect, which is absent in the thin layer of the first surface and is essential for energy losses in the thin layer near the second surface.

This phenomenon was discovered in the interaction of ultrarelativistic electrons and positrons with silicon and niobium single crystals [8 - 12].

The aim of this work is to carry out experimental and theoretical studies of the yield of low-energy and $\delta$ electrons from amorphous aluminum targets with a thickness of 8 and $50 \mu \mathrm{m}$ in the range of electron ener- gies up to $30 \mathrm{MeV}$, as well as to experimentally measure the influence of the density effect on the yield of low-energy electrons.

\section{THE SECONDARY ELECTRON EMISSION YIELD MODELING OF ALUMINUM FOILS}

The modeling of a possible physical effect was carried out using the Berger-Seltzer formula in the following form [13]:

$$
\begin{aligned}
& \frac{d E}{d x}=2 \pi r_{e}^{2} m c^{2} n_{e l} \frac{1}{\beta^{2}} \times \\
& \times\left[\ln \frac{2(\gamma+1)}{\left(I / m c^{2}\right)^{2}}+F^{ \pm}\left(\tau, \tau_{u p}\right)-\delta\right],
\end{aligned}
$$

where $d E / d x$ is the ionization losses; $F^{ \pm}$is the function that determines the energy transfer by secondary electrons; $\delta$ is the parameter that takes into account the density effect in the case of complete compensation of the relativistic effect inside the target.

It can be assumed that the number of generated electrons in a thin layer of the target will be proportional to the lost energy by the initial electron without taking into account the density effect and taking into account the entrainment of energy by delta electrons, and the exit from the second surface will be proportional to the energy lost by the electron, taking into account the effect of density and entrainment of energy by delta electrons.

To simulate this process on the left side of the equation, we used the data on ionization losses from [14], as well as the $\delta$-values. The function $F^{ \pm}$, which determines the energy removal from the target, was simulated by the Geant 4.9.1 toolkit [15] and subtracted from the value of ionization losses (1). Further, the value of ionization losses was calculated without taking into account the density effect $(\delta)$, and taking it into account, and their ratio was found.

In Table 1 the calculation results for $A l$ thicknesses of 8 and $50 \mu \mathrm{m}$ are presented.

From the calculations, it can be concluded that the ratio $(d E / d x-F-\delta) /(d E / d x-F)$ in this range depends on the initial energy of the electron and does not depend on the thickness of the target. 
Table 1 thickness of 8 and $50 \mu \mathrm{m}$. As collectors were used alu-

Calculation results Al foils 8 and $50 \mu \mathrm{m}$

\begin{tabular}{|c|c|c|c|c|}
\hline \multicolumn{5}{|c|}{$8 \mu \mathrm{m}$} \\
\hline $\begin{array}{l}E e, \\
\mathrm{MeV}\end{array}$ & $\begin{array}{c}d E / d x \\
\mathrm{keV}\end{array}$ & $\begin{array}{c}d E / d x-F, \\
\mathrm{keV}\end{array}$ & $\begin{array}{c}d E / d x-F-\delta \\
\mathrm{keV}\end{array}$ & $\begin{array}{c}(d E / d x-F-\delta) / \\
(d E / d x-F)\end{array}$ \\
\hline 2.5 & 3.22 & 2.51 & 2.65 & 1.06 \\
\hline 10 & 3.53 & 2.98 & 3.46 & 1.16 \\
\hline 15 & 3.62 & 2.97 & 3.6 & 1.21 \\
\hline 20 & 3.68 & 3.09 & 3.85 & 1.24 \\
\hline 25 & 3.72 & 3.2 & 4.05 & 1.27 \\
\hline \multicolumn{5}{|c|}{$50 \mu \mathrm{m}$} \\
\hline 2.5 & 20.15 & 17.14 & 18.01 & 1.05 \\
\hline 10 & 22.09 & 17.86 & 20.88 & 1.17 \\
\hline 15 & 22.63 & 18.26 & 22.23 & 1.22 \\
\hline 20 & 23.0 & 18.74 & 23.45 & 1.25 \\
\hline 25 & 23.29 & 19.05 & 24.37 & 1.28 \\
\hline
\end{tabular}

The Geant 4.9.1 toolkit also allows calculating the secondary electron yields. The dependence of $\delta$-electrons yields on the primary electron energy and target thickness are shown in Fig. 1.

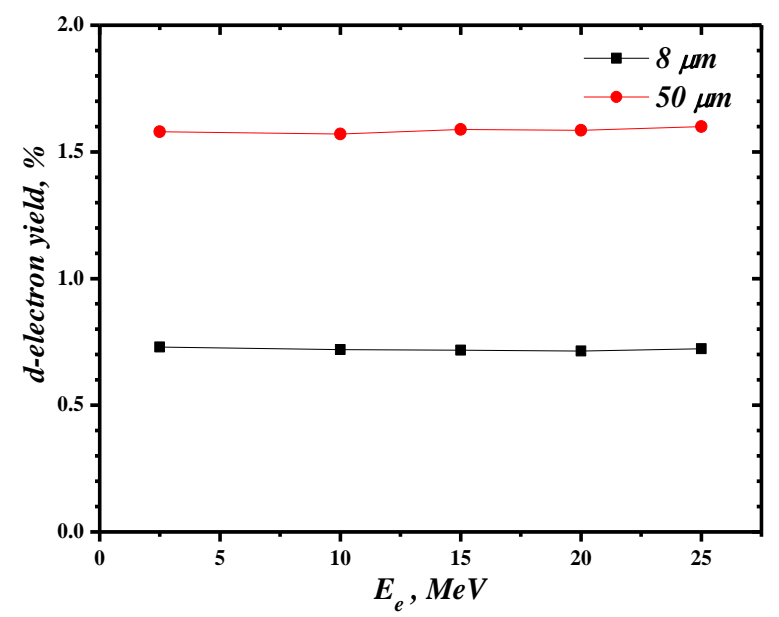

Fig. 1. Energy dependence of $\delta$-electron yields from 8 and $50 \mu \mathrm{m}$ aluminum foils

In the studied energy range, there is practically no dependence of the yield of $\delta$-electrons on the initial energy of electrons, but there is a dependence on the thickness of the target.

The density effect reduces the ionization losses of the beam with an increase in its energy. This phenomenon is associated with the screening of the field of the relativistic electron. Shielding occurs at a certain depth of passage of the primary electron.

The yield of secondary electrons from the first surface of the target, relative to the direction of the electron beam, is observed experimentally, more than from the second.

\section{EXPERIMENTAL RESEARCH OF SECONDARY ELECTRON EMISSION}

The schematic of the experiment is shown in Fig. 2. The initial energy of electrons was 15 and $30 \mathrm{MeV}$. The dimension of the electron beam is $\sim 7 \mathrm{~mm}$. The primary electron beam current did not exceed up $2 \mu \mathrm{A}$. The beam dimensions were formed using replaceable collimators with a diameter of 4 to $10 \mathrm{~mm}$ (not shown on the Fig. 2). The targets (emitters) were aluminum foils with minum plates with a hole in the center with a diameter of $16 \mathrm{~mm}$. The distance between the emitter and the collectors is $5 \mathrm{~mm}$. The collectors were supplied with voltages ranging from -100 to $+150 \mathrm{~V}$.

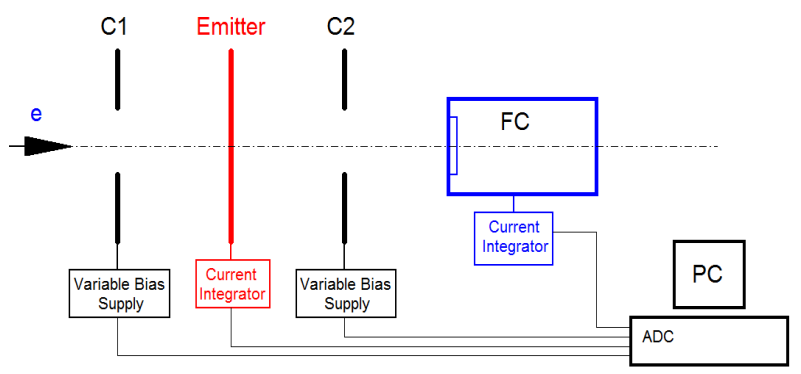

Fig. 2. The general scheme of the experiment for research the SEE yields

Electronic currents from the emitter and the Faraday cup (FC) were measured using an automated system based on a universal gated integrating current voltage converter [16]. The convertor has two independent measurements channels (first current range is from -5 to $+5 \mathrm{nA}$ for emitter current measurements and second from -5 to $+5 \mu \mathrm{A}$ for total electron beam current measurements by FC) and communicates with the PC by Atmega328 microprocessor via USB interface. At a voltage of $-50 \mathrm{~V}$, the yield of low-energy electrons at the collectors was shut off and the yield of $\delta$-electrons from the emitter was recorded. At a voltage of $+50 \mathrm{~V}$, the formed low-energy electrons were completely extracted out of the emitter. By varying the voltage on different collectors, it is possible to determine the yield of low-energy electrons from the first and second surfaces. When voltage $\geq-50 \mathrm{~V}$ is applied to both collectors, the electron current from the emitter will be due to the emission of $\delta$-electrons. On Fig. 3,a,b shows the $\mathrm{V}$-A characteristics of an $A l$ emitter with a thickness of 8 and $50 \mu \mathrm{m}$ for a primary electron beam energy of 16 and $25 \mathrm{MeV}$, respectively.

The experimental data on the V-A characteristics were fitted applying the formula:

$$
\text { SEEYield, } \%=\frac{A_{1}-A_{2}}{1+e^{\left(U-U_{0}\right) / d U}}+A_{2},
$$

which is the Boltzmann distribution function, where SEEYield - percentage value of secondary electron emission yield; $A_{1}$ - the lower saturation region, corresponds to the yield of delta electrons; $A_{2}$ is the upper saturation region, corresponds to the total yield of secondary electrons; $U$ is the value of the potential at $C l=$ $C 2, C 1$ and $C 2, U_{0}$ is the distribution center; $d U-$ constant voltage.

The experimental data fitting and processing results of the SEE yields from Fig. 3,a,b are presented in the Table 2.

In the Table 3 the calculated and experimental values of $N_{1}$ and $N_{2}$ for an $A l$ target with a thickness of 8 and $50 \mu \mathrm{m}$ by formulas (1) and (2) respectively are presented, where $N_{l}$ - the total low energy secondary electron yields from the first surface and $N_{2}$ - the total low energy secondary electron yields from the second surface and $N_{l} / N_{2}$ - the ratio and main determined parameter of density effect existence. 

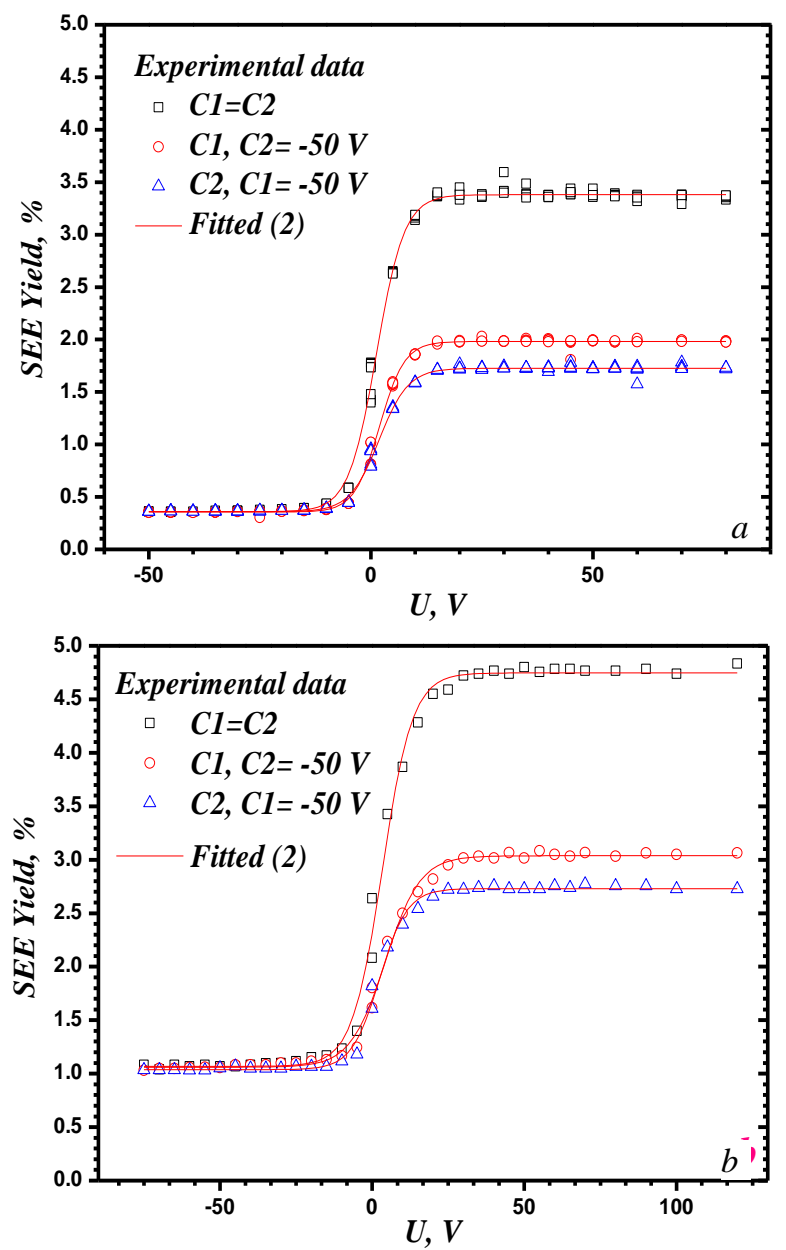

Fig. 3. Experimental $V$-A characteristics of Al foils:

$8 \mu \mathrm{m}$ thickness, $E_{\text {primary }}=16 \mathrm{MeV}(a)$;

$50 \mu \mathrm{m}, E_{\text {primary }}=25 \mathrm{MeV}(\mathrm{b})$

Table 2

Experimental data analysis

\begin{tabular}{|c|c|c|c|}
\hline \multicolumn{4}{|c|}{$E_{\text {primary }}=16 \mathrm{MeV}$ with Al foil $8 \boldsymbol{\mu m}$} \\
\hline \multirow{8}{*}{$C 1=C 2$} & & Value & $\begin{array}{l}\text { Standard } \\
\text { Error }\end{array}$ \\
\hline & Reduced Chi-Sqr & 0.004 & - \\
\hline & Adj. R-Square & 0.997 & - \\
\hline & $A_{1}$ & 0.36 & 0.012 \\
\hline & $A_{2}$ & 3.38 & 0.008 \\
\hline & $U_{0}$ & 1.3 & 0.089 \\
\hline & $d U$ & 3.12 & 0.095 \\
\hline & $A_{2}-A_{1}$ & 3.02 & - \\
\hline \multirow{7}{*}{$C 1$} & Reduced Chi-Sqr & 0.001 & - \\
\hline & Adj. R-Square & 0.998 & - \\
\hline & $A_{1}$ & 0.36 & 0.004 \\
\hline & $A_{2}$ & 1.98 & 0.004 \\
\hline & $U_{0}$ & 1.93 & 0.076 \\
\hline & $d U$ & 2.81 & 0.068 \\
\hline & $N_{1}=A_{2}-A_{1}$ & 1.62 & - \\
\hline \multirow{7}{*}{$C 2$} & Reduced Chi-Sqr & $8.6 \mathrm{E}-4$ & - \\
\hline & Adj. R-Square & 0.997 & - \\
\hline & $A_{1}$ & 0.36 & 0.004 \\
\hline & $A_{2}$ & 1.73 & 0.003 \\
\hline & $U_{0}$ & 1.85 & 0.081 \\
\hline & $d U$ & 3.27 & 0.078 \\
\hline & $N_{2}=A_{2}-A_{1}$ & 1.37 & - \\
\hline
\end{tabular}

\begin{tabular}{|c|c|c|c|}
\hline \multicolumn{4}{|c|}{$E_{\text {primary }}=25 \mathrm{MeV}$ with Al foil $\mathbf{5 0} \boldsymbol{\mu m}$} \\
\hline \multirow{8}{*}{$C 1=C 2$} & & Value & $\begin{array}{c}\text { Standard } \\
\text { Error }\end{array}$ \\
\hline & Reduced Chi-Sqr & 0.011 & - \\
\hline & Adj. R-Square & 0.996 & - \\
\hline & $A_{1}$ & 1.07 & $\mathbf{0 . 0 3}$ \\
\hline & $\overline{A_{2}}$ & 4.75 & 0.03 \\
\hline & $U_{0}$ & 3.317 & 0.35 \\
\hline & $d U$ & 4.97 & 0.32 \\
\hline & $A_{2}-A_{1}$ & 3.68 & - \\
\hline \multirow{7}{*}{$C l$} & Reduced Chi-Sqr & 0.003 & - \\
\hline & Adj. R-Square & 0.996 & - \\
\hline & $A_{I}$ & 1.06 & 0.014 \\
\hline & $A_{2}$ & 3.04 & 0.014 \\
\hline & $U_{0}$ & 4.29 & 0.35 \\
\hline & $d U$ & 5.73 & 0.32 \\
\hline & $N_{I}=A_{2}-A_{I}$ & 1.98 & - \\
\hline \multirow{7}{*}{$C 2$} & Reduced Chi-Sqr & 0.0022 & - \\
\hline & Adj. R-Square & 0.996 & - \\
\hline & $A_{1}$ & 1.04 & 0.013 \\
\hline & $A_{2}$ & 2.73 & 0.012 \\
\hline & $U_{0}$ & 2.39 & 0.316 \\
\hline & $d U$ & 4.56 & 0.305 \\
\hline & $N_{2}=A_{2}-A_{I}$ & 1.69 & - \\
\hline
\end{tabular}

Table 3

Low energy electron yields comparison analysis for Al foils 8 and $50 \mu \mathrm{m}$

\begin{tabular}{|c|c|c|c|}
\hline \multirow{2}{*}{$E, \mathrm{MeV}$} & \multicolumn{3}{|c|}{ Calculated data } \\
\cline { 2 - 4 } & $N_{1}$ & $N_{2}$ & $N_{l} / N_{2}$ \\
\hline 16 & 0.0215 & 0.0178 & 1.2 \\
\hline 25 & 0.0227 & 0.018 & 1.26 \\
\hline & \multicolumn{3}{|c|}{ Experimental data } \\
\hline$E, \mathrm{MeV}$ & $N_{l}$ & $N_{2}$ & $N_{l} / N_{2}$ \\
\hline 16 & 0.0162 & 0.0137 & 1.18 \\
\hline 25 & 0.0198 & 0.0169 & 1.17 \\
\hline
\end{tabular}

\section{CONCLUSIONS}

The SEE yield research was carried out when relativistic electrons with energies of 16 and $25 \mathrm{MeV}$ pass through $A l$ targets of 5 and $80 \mu \mathrm{m}$. The yield of low energy electron yield was investigated as a function of the potential on the collectors in the range of -50 to $+120 \mathrm{~V}$. The excess of the yield of low-energy electrons from the first surface over the yield from the second was established, which indicates the influence of the density effect on ionization losses. The experimental results agree with the calculated ones within the experimental errors. The difference in the experimental and calculated data on the yields of $\delta$-electrons is due to the design features of secondary emission monitor. It is shown that the yields of low-energy electrons depend on the initial energy of the beam, while the yields of delta electrons depend only on the thickness of the target in a given energy range.

\section{REFERENCES}

1. V.B. Ganenko, S.P. Gokov, Yu.H. Kazarinov, S.H. Karpus, et al. Experimental facility for investigation of electron beams interaction with single crystals and amorphous targets // Abstracts of XXVII 
International conference on Charged Particle Accelerators. Kharkiv. KIPT September 21-24, 2021, p. 19-20.

2. B. Planskov. Secondary electron emission in high energy beam monitors // NIM. 1963, v. 24(2), p. $172-180$.

3. G.F. Dell, M. Fotino. Secondary emission yield by extreme relativistic particles // Phys. Lett. 1969, v. 29 , v. 5 , p. $324-326$.

4. V.A. Gol'dshteyn, I.M. Arkatov, V.I. Startsev. Monitor vtorichnoy emissii na del'ta-elektronakh // Pribory i Tekhnika Eksperimenta. 1973, v. 2, p. 5051 (in Russian).

5. A.P. Klyucharev, V.A. Stratiyenko, G.D. Kovalenko, V.A. Skubko, V.V. Tovstyak. O monitorirova-nii parametrov puchkov elementarnykh chastits i gamma-kvantov na osnove delta-elektronov // Metrologiya. 1974, № 8, p. 67-69 (in Russian).

6. V.I. Vanhuyse R.E. Van de Vijver. Efficiency of secondary emission for electron beams // NIM. 1962, v. $15(1)$, p. 63-68.

7. G.D. Kovalenko, S.H. Karpus, Yu.H. Kazarinov, V.N. Borysenko, S.S. Kochetov, Ye.V. Tsyatsko, O.O. Shopen, V.Y. Kasilov. Analysis of secondary electron emission measurement systems // Abstracts of XXVII International conference on Charged Particle Accelerators. Kharkiv, KIPT. September 21-24. 2021, p. 62-63.

8. I.A. Grishayev, G.D. Kovalenko, B.I. Shramenko Elektronnaya emissiya iz monokristalla niobiya, vyzvannaya ul'trarelyativistskimi elektronami // Pis'ma v ZHTF. 1979, v. 5, iss. 18, p. 1104-1107 (in Russian).
9. G.D. Kovalenko. Emissiya vtorichnykh elektronov iz monokristallov kremniya i niobiya pod deystviyem ul'trarelyativistskikh elektronov // UFZH. 1981, v. 26, iss. 11, p. 1839-1843 (in Russian).

10. D.I. Adeyshvili, G.L. Bochek, V.I. Vit'ko, G.D. Kovalenko, B.I. Shramenko. Dekanalirovaniye elektronov s energiyey $1200 \mathrm{MeV}$ v monokristalle kremniya // Pis'ma v ZHTF. 1984, v. 10, iss. 4, p. 197-200 (in Russian).

11. V.I. Vit'ko, G.D. Kovalenko. Vykhod vtorichnykh elektronov pri vzaimodeystvii ul'trarelyativistskikh elektronov i pozitronov s monokristallami // ZHETF. 1988, v. 94, iss. 10, p. 321-327 (in Russian).

12. G.L. Bochek, V.I. Vit'ko, G.D. Kovalenko, B.I. Shramenko. Eksperimental'nyye issledovaniya elektromagnitnykh protsessov $v$ monokristallakh: Preprint. Khar'kov: NNTS KHFTI. 1998, 112 p. (in Russian)

13. H. Messel and D.F. Crawford. Pergamon Press. Oxford. 1970, $1512 \mathrm{p}$.

14. National Standards and Technology /Physical Measurement Laboratory https://www.nist.gov/pml/

15. S. Agostinelli, J. Allison, K. Amako and others. Geant4-a simulation toolkit // Nuclear Instruments and Methods in Physics Research A. 2003, v. 506, iss. 3, p. 250-303.

16. G.P. Vasiliev, S.K. Kiprich, A.A. Kapliy, G.D. Kovalenko, M.I. Maslov, V.D. Ovchinnik, S.M. Potin, M.Yu. Shulika, I.N. Shliakhov, V.I. Yalovenko. Gated integrating current-voltage convertor for measuring low currents // Abstracts of XXVII International conference on Charged Particle Accelerators. Kharkiv, KIPT. September 21-24, 2021, p. 94-95.

Article received 06.10 .2021

\section{ВТОРИЧНАЯ ЭМИССИЯ ЭЛЕКТРОНОВ ИЗ ТОНКИХ АЛЮМИНИЕВЫХ ФОЛЬГ НА ПУЧКАХ ВИСОКОЭНЕРГЕТИЧНЫХ ЭЛЕКТРОНОВ \\ С.Г. Карпусь, Г.Д. Коваленко, Ю.Г. Казаринов, В.Н. Дубина, В.И. Касилов, С.С. Кочетов, О.А. Шопен, И.Н. Шляхов}

Приведено описание экспериментального оборудования и методики измерения вторичной эмиссии электронов (ВЭЭ) с использованием ускоренных электронов на линейном ускорителе ИФВЭЯП ННЦ ХФТИ с энергиями до 30 МэВ и стандартном мониторе вторичной эмиссии [1]. Экспериментально измерены выходы вторичной электронной эмиссии из тонких алюминиевых мишеней (8 и 50 мкм) при энергиях первичного электронного пучка 16 и 25 МэВ. Проведен анализ экспериментальных данных и их сравнение с теорией. Показано, что предложенная методика измерения выходов вторичной эмиссии электронов позволяет получать данные по выходам низкоэнергетических и $\delta$-электронов, а также исследовать влияние эффекта плотности в зависимости от энергии первичного пучка электронов.

\section{ВТОРИННА ЕМІСІЯ ЕЛЕКТРОНІВ 3 ТОНКИХ ПЛІВОК АЛЮМІНІЮ НА ПУЧКАХ ВИСОКОЕНЕРГЕТИЧНИХ ЕЛЕКТРОНІВ}

\section{С.Г. Карпусь, Г.Д. Коваленко, Ю.Г. Казарінов, В.М. Дубіна, В.Й. Касілов, С.С. Кочетов, О.О. Шопен, І.М. Шляхов}

Надано опис експериментального обладнання та методики вимірювання виходів вторинної емісії електронів (ВЕЕ) при використанні пучка прискорених електронів на лінійному прискорювачі ІФВЕЯФ ННЦ ХФТІ з енергією до $30 \mathrm{MeB}$ і стандартного монітора вторинної емісії [1]. Отримано експериментальні дані по виходах вторинної емісії електронів з тонких мішеней алюмінію ( 8 і 50 мкм) для енергії первинного пучка електронів 16 і 25 МеВ. Проведено аналіз експериментальних даних і порівняння їх з теорією. Показано, що запропонована методика вимірювання виходів вторинної емісії електронів дозволяє отримувати дані по виходах низькоенергетичних і $\delta$-електронів, а також дослідити вплив ефекту густини в залежності від енергії первинного пучка електронів. 